\title{
National Seminar cum Workshop on Environment and Sustainable Development in Mineral Industry and Solid Waste Management (ESD-MISM-2011) - C. Kasipathi
}

A national seminar cum workshop on environment, mineral industry, solid waste management was organized during 14-15 March 2011. The main objective of the seminar was to address some of the important environmental issues related to mineral industries and to evolve suitable methodologies to maintain the best practices in environment management.

Seven technical sessions on environmental geology, geo-environment and management, environmental pollution of fuel resource, environment - mining sustainable development, solid waste management, best practices in environmental management: practical approach and remote sensing and GIS in environment were conducted in the two-day programme. About 60 research papers were received and only 33 papers were included in the pre-Seminar proceedings after peer review. About 100 delegates from various Universities, National institutes, Industries and Entrepreneurs participated and deliberated on various aspects of the seminar themes.

The seminar was inaugurated by Prof. Beela Satyanarayana, Hon'ble ViceChancellor, Andhra University and the keynote address was presented by Shri M.S. Murty, Chief Mining Geologist, IBM (retd.) and Dr. S. Ramgopal of M/s. Savvy Projects Pvt.Ltd. Prof. C. Kasipathi, Convenor of Seminar, conducted the proceedings of the Seminar.

The following recommendations were made in the concluding session of the Seminar by the technical session chairmen, Guests of honours, mine owners, industry persons, participants and the Convenor.

1. Mines which are clustered in a mineralized belt share the same resources (infrastructure, and logistics) from the nearby areas, which has direct bearing and cumulative impact on local and regional environment. It is suggested to conduct Regional Environmental Assessment (REA) and Environmental Impact Assessment (EIA) to gain a better understanding on environmental pollution and its mitigation.

2. There is a need to work out alternate methodologies to minimize or reduce waste quantities generated at the mines. This can be accomplished by steepening the pit slopes to a reasonable degree with safety considerations.

3. There is a need to develop national data bank on different types of waste generated, accumulated, chemical and physical characteristics of waste forming minerals and its possible utilization, R\&D efforts to develop alternate strategies for waste utilization should be taken up immediately.

4. The grade of exportable iron ore has dropped due to Chinese and other international markets. The threshold value for iron ore is $46 \% \mathrm{Fe}$, as per IBM norms. The lowering of threshold value will increase the reserve base of iron ore considerably and occupies more area. Blending the low grade ore with high grade can be thought of to make marketable grades.

5. Due to the presence of large mining companies, the small scale mining activity is not gaining much importance. Barring few minerals, majority of minerals are produced by small-scale mining, which needs to be encouraged by providing financial assistance.

6. For the benefits of the mineral industry, the government should carry out with mutually agreed standards, for mine effluents and other environmental parameters by MOEF, MOM, and $\mathrm{CPCB}$ and SPCB for establishing standards for non-coal mines along "with procedure for conducting environmental monitoring. Such standards are already available for coal mines.

7. It is proposed that royalties and levies, with some additional load on industry if required be distributed judiciously for development of affected communities and to fund $R \& D$ projects by institutions which may benefit the mining industry.

8. Steps to be taken up to check and control air pollution in and around Visakhapatnam due to handling of ores in the port area, which is affecting the local population.

9. Social awareness to be created among the local communities, government and industry to make sustainable development of mineral industry more meaningful.

10. The small-scale mining sector and rockforming mineral mining industries should be protected from the stringent mining and environmental rules and regulations, as they cannot bear to withstand the consequences. 